\title{
Nutritional value of sugarcane varieties in relation to nitrogen fertilization for the pre-Amazon Region of Brazil
}

\section{Valor nutritivo de variedades de cana-de-açúcar em função da adubação nitrogenada na região pré-Amazônica do Brasil}

\author{
Mayanna Karlla Lima Costa ${ }^{1}$; Francirose Shigaki ${ }^{*}$; José Roberto Brito Freitas ${ }^{2}$; \\ Rosane Cláudia Rodrigues ${ }^{2}$; Heloisa Carneiro ${ }^{3}$
}

\begin{abstract}
This study evaluated the nutritional value of sugarcane varieties in relation to nitrogen fertilization. The varieties studied were RB 863129, RB 867515, and RB 92579, and nitrogen fertilizer was applied at doses of $0,60,80,120$, and $140 \mathrm{~kg} \mathrm{~N} \mathrm{ha}^{-1}$. The experiment was divided into two stages: i) Year I - plant cane, when the yield and nutritional quality of the three sugarcane varieties were evaluated; ii) Years II and III, when and the effect of nitrogen fertilization on the nutritional quality of the first and second ratoon crops of the same varieties was evaluated. In plant cane the yield $\left(\mathrm{t} \mathrm{ha}^{-1}\right)$ and DM (dry matter) and $\mathrm{CP}$ (crude protein) contents were higher for the RB 863129 variety. There was no difference between the varieties regarding their NDF (neutral detergent fiber) and ADF (acid detergent fiber) contents and IVDMD (in vitro dry matter digestibility). In the first and second ratoon crops, there was a difference between the varieties and fertilizer doses for the evaluated parameters, with the exception of the DM content and IVDMD, which were influenced by the varieties, doses of $\mathrm{N}$, and cutting years. The RB 92579 variety showed the best yield of the two ratoon crops (131 tha-1 of stems) and the best nutritional parameters ( $26 \% \mathrm{ADF}, 41 \% \mathrm{NDF}, 2.4 \% \mathrm{CP}$, and $69.4 \%$ IVDMD). The sugarcane yield and its nutritional quality can be influenced by the cutting year and nitrogen fertilization management system and by the variety type.
\end{abstract}

Key words: In vitro digestibility. Animal nutrition. Saccharum officinarum.

\section{Resumo}

Este estudo avaliou o valor nutritivo de variedades de cana-de-açúcar em função da adubação nitrogenada. As variedades estudadas foram RB 863129, RB 867515 e RB 92579, e as doses nitrogenadas 0, 60, 80, 120 e $140 \mathrm{~kg} \mathrm{~N} \mathrm{ha}^{-1}$. O experimento foi dividido em duas etapas: i) Ano I - Cana-planta: avaliou-se a produtividade e qualidade nutricional de três variedades de cana-de-açúcar; ii) Anos II e III: avaliou-se a influência da adubação nitrogenada na qualidade nutricional da primeira e segunda soca das mesmas variedades. Na cana-planta foram determinados o teor de Brix e a relação FDN/Brix. Para a cana-planta, a produtividade $\left(\mathrm{t} \mathrm{ha}^{-1}\right)$ e os teores de MS e $\mathrm{PB}$, foram superiores $(\mathrm{P}<0.05)$ para a variedade $\mathrm{RB} 863129$. Não houve diferença $(P<0,05)$ entre as variedades para os teores de FDN e FDA e para a DIVMS. Na primeira e segunda soqueira houve diferença $(\mathrm{P}<0,05)$ entre variedades e doses de adubação para os parâmetros avaliados, com exceção do teor de MS e digestibilidade in vitro, que foram influenciados

\footnotetext{
${ }^{1}$ Discente de Doutorado, Programa de Pós-Graduação em Biodiversidade e Conservação, Rede Bionorte, Universidade Federal do Maranhão, UFMA, São Luís, MA, Brasil. E-mail: mayannakarlla@hotmail.com

2 Profs., UFMA, Chapadinha, MA, Brasil. E-mail: francirose@yahoo.com.br; joserobertobritofreitas@yahoo.com.br; rosanerodrig@gmail.com

${ }^{3}$ Pesquisadora, Empresa Brasileira de Pesquisa Agropecuária no Centro Nacional de Pesquisa de Gado de Leite, EMBRAPA, Juiz de Fora, MG, Brasil. E-mail: heloisa.carneiro@embrapa.br

* Author for correspondence
} 
$(\mathrm{P}<0,05)$ pelas variedades, doses de $\mathrm{N}$ e anos de corte. A variedade RB 92579 apresentou nas duas soqueiras a melhor produtividade (131 t ha- ${ }^{-1}$ de colmos), aliada aos melhores parâmetros nutricionais (FDA $26 \%$, FDN 41\%, PB 2,4\% e DIVMS 69,4\%). A produtividade da cana-de-açúcar, assim com a sua qualidade nutricional, pode ser influenciada pelo manejo da adubação nitrogenada, ano de corte e pela variedade.

Palavras-chave: Digestibilidade in vitro. Nutrição animal. Saccharum officinarum.

\section{Introduction}

In pasture-based ruminant production, the primary problem faced by farmers is the seasonality of forage production, which is responsible for oscillations in animal production. Such variations arise from the fact that approximately $80 \%$ of the forage dry matter produced in pastures during the year is available only in the rainy season, which makes the dry season a critical period in which forage production is insufficient (BONOMO et al., 2009). Considering this situation, the search for alternative food sources to supply the roughage shortage during the dry season and to meet the nutritional requirements of the animals is of the utmost importance.

Sugarcane is used as an alternative food product for a variety of reasons, which include its high dry matter (DM) production per hectare, ease of cultivation, hardiness, and, primarily, high dry matter digestibility even when the plant reaches maturity. The latter factor confers sugarcane an advantage as a forage plant because tropical forages suffer quantitative and qualitative losses during the dry season, which is when sugarcane contains the highest energy content in the form of sucrose (ABRANCHES; BOLONHEZI, 2011). Various studies have been performed on the use of sugarcane as animal feed; however, the nutritional value of this crop has been the object of much discussion, primarily with regard to identifying varieties with more suitable characteristics for forage production and with regard to management (SIQUEIRA et al., 2012). The hypothesis postulated by Boin et al. (1987), i.e., that the best forage sugarcane varieties are those that exhibit a high proportion of leaves and stems relative to the total green matter, is no longer supported because the green matter yield and nutritional value must also be considered together with the sugar content and neutral detergent fiber fraction (NDF). This last factor directly influences the dry matter digestibility and intake (BERCHIELLI et al., 2011), and thus, varieties can differ in terms of their nutritional quality (ANON, 2007).

According to Scarpari and Beauclair (2009), different sugarcane varieties exhibit different maturation curves with differences in sucrose percentages and flowering. Variations in the contents of crude protein $(\mathrm{CP})$, neutral detergent fiber, acid detergent fiber (ADF), and dry matter digestibility (DMD) were observed by Carvalho et al. (2010).

In addition to variety type, another factor that can influence the nutritional quality of sugarcane for animal feeding is nitrogen fertilization management; however, studies on this subject are still scarce. Nitrogen $(\mathrm{N})$ is one of the essential nutrients required most in terms of quantity by sugarcane, which has a C4 metabolism. This type of metabolism is characterized by a high photosynthetic rate and thus requires an adequate supply of $\mathrm{N}$ for the physiological processes and the biochemical reactions responsible for photosynthesis to process satisfactorily (MUCHOVEJ; NEWMAN, 2004). Thus, the large demand by sugarcane for this nutrient makes the participation of $\mathrm{N}$ in the production process substantial relative to the total cost of implementation and maintenance of sugarcane fields (RAKKIYAPPAN et al., 2007). However, considering the requirement for $\mathrm{N}$ by sugarcane crops, the $\mathrm{N}$ dynamics in the soil, the biochemical processes that involve $\mathrm{N}$ assimilation, and the aspects related to the use of nitrogen fertilization, primarily regarding their possible effects on the nutritional quality of sugarcane, must be better 
clarified; the available studies in literature mostly focus on other tropical forage plants. In the study by Waramit et al. (2012), the authors evaluated the influence of three doses of $\mathrm{N}(0,65$, and $140 \mathrm{~kg} \mathrm{~N}$ $\mathrm{ha}^{-1}$ ) on the nutritional value of four forage grasses, namely, Indiangrass (Sorghastrum mutans L. Nash), big bluestem (Andropogon gerardii Vitman), Eastern gamagrass (Tripsacum dactyloides L.), and switchgrass (Panicum virgatum L.). The results showed that nitrogen fertilization significantly increased $(\mathrm{P}<0.05)$ the values of in vitro dry matter digestibility (IVDMD) and crude protein in the four grass species evaluated, and the best NDF value $(52 \%)$ was obtained with the intermediate fertilizer dose of $65 \mathrm{~kg} \mathrm{~N} \mathrm{ha}^{-1}$.

In addition to the possible effect on the nutritional quality of sugarcane, the adequate management of nitrogen fertilization can contribute greatly to the sustainability of agro-ecosystems.

Thus, the objective of this study is to evaluate the nutritional value of sugarcane varieties in relation to nitrogen fertilization for the Pre-Amazon region of Brail, where these studies are just beginning.

\section{Materials and Methods}

\section{Description of the experimental area}

The experiment was performed in an area provided by the Várzea Farm in the municipality of Brejo, Lower Parnaíba Region, state of Maranhão, Brazil, which is located at $03^{\circ} 44^{\prime} 33^{\prime \prime} \mathrm{W}$ latitude, $43^{\circ} 21^{\prime} 21$ ' W longitude. The soil was classified as a Yellow Latosol (Oxisol) (Embrapa Manual for Soil Classification, 1997) and exhibited the following characteristics: $\mathrm{pH} 5.12$ in water, $2.2 \mathrm{cmolc} \mathrm{dm}^{-3} \mathrm{Ca}$, $2.5 \mathrm{cmolc} \mathrm{dm}^{-3} \mathrm{Mg}, 0.02 \mathrm{cmol}_{\mathrm{c}} \mathrm{dm}^{-3} \mathrm{Na}, 0.11 \mathrm{cmol}_{\mathrm{c}}$ $\mathrm{dm}^{-3} \mathrm{~K}, 0.6$ cmolc dm ${ }^{-3} \mathrm{Al}, 9.4$ cmolc dm$^{-3} \mathrm{H}+\mathrm{Al}$, and $2.5 \mathrm{mg} \mathrm{kg}^{-1} \mathrm{P}$.

\section{Experimental setup}

The experiment began in 2009 with conventional soil tillage, and the planting was performed in $30-\mathrm{cm}$ deep furrows spaced $1.00 \mathrm{~m}$ apart. The seedlings, which were aged between 10 and 12 months, were placed in the bottom of the furrows with the basal portion of a seedling in contact with the apical portion of the subsequent one. After the seedlings were manually cut using a knife into billets with three to four buds, the billets were placed in the furrows, which were then covered with approximately $10 \mathrm{~cm}$ of loose soil. Fertilization at planting was performed according to the soil analysis recommendations, using $120 \mathrm{~kg} \mathrm{ha}^{-1} \mathrm{P}_{2} \mathrm{O}_{5}$ and $100 \mathrm{~kg} \mathrm{ha}^{-1} \mathrm{~K}_{2} \mathrm{O}$. The experiment lasted three years (Year I - Plant cane, Year II - first ratoon, and Year III - second ratoon). The temperature and precipitation data were obtained through the RealTime Climate Monitoring Program of the Northeast Region (Programa de Monitoramento Climático em Tempo Real da Região Nordeste - PROCLIMA) at the site of the CPTEC INPE (Figures 1, 2, and 3).

The experiment was divided into two stages: a) in the first stage, which consisted of the first experimental year (Year I), the yield and nutritional quality of the three sugarcane varieties (plant cane) were evaluated; b) in the second stage, which consisted of the second and third years (Year II and Year III), the effect of nitrogen fertilization on the nutritional quality of the same varieties evaluated in the first year was evaluated, though for the first and second ratoon crops. The varieties evaluated were RB 863129, RB 867515, and RB 92579.

An experimental design in randomized blocks with three treatments (sugarcane varieties) and three replicates (experimental plots) was adopted for Year I, where in each experimental plot had an area of $900 \mathrm{~m}^{2}$, with a total area of $8,100 \mathrm{~m}^{2}$. 
Figures 1 and 2. Precipitation and air temperature- Year 1; Precipitation and air temperature- Year 2.
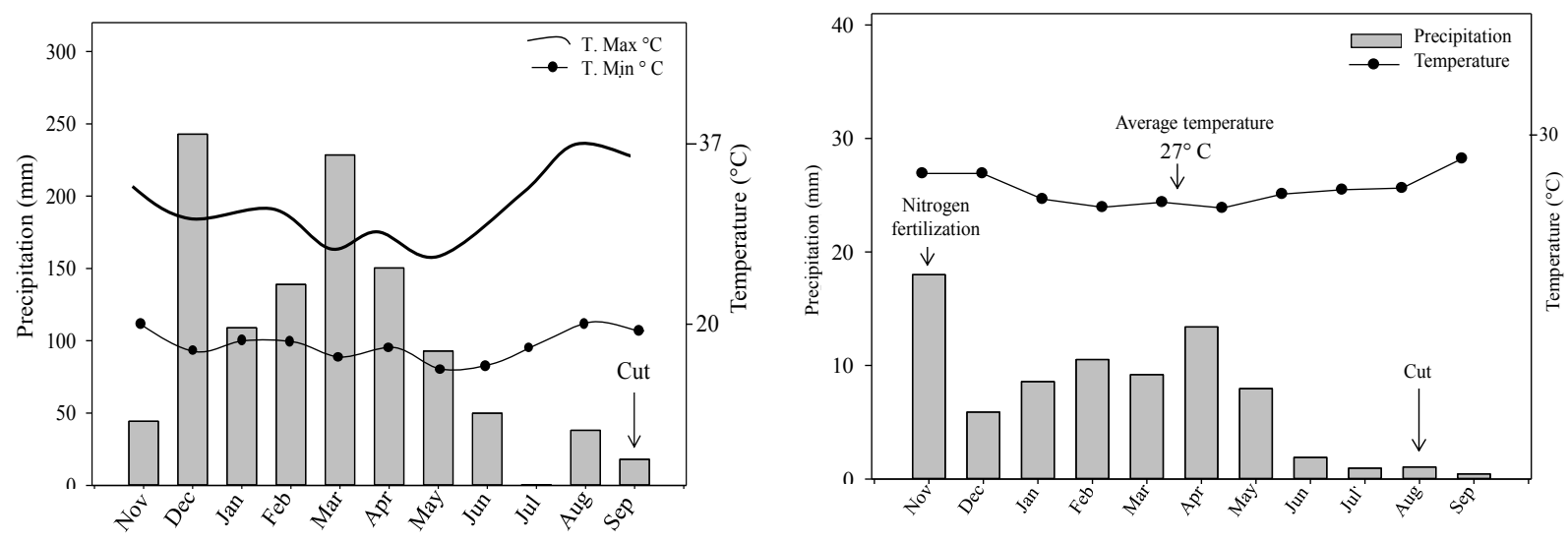

Figure 3. Precipitation and air temperature- Year 3.

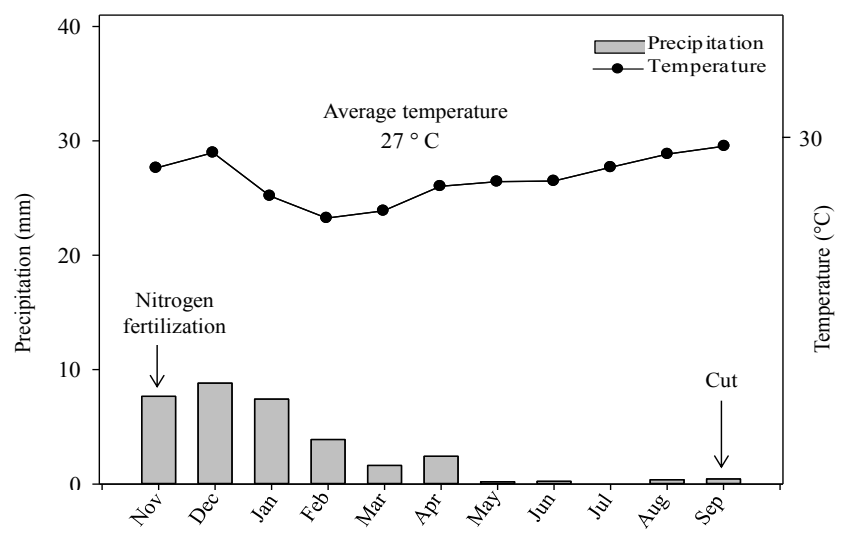

For the evaluations of Years II and III, the plots from Year I were divided into sub-plots where different doses of $\mathrm{N}$ were applied, which also adopted a randomized block design, with a $5 \times 3 \times 2$ factorial arrangement with five doses of nitrogen fertilizer $\left(0,60,80,120\right.$, and $\left.140 \mathrm{~kg} \mathrm{~N}^{-1}\right)$, three sugarcane varieties (RB 867515, RB 863129, and RB 92579) and two periods (1st and 2nd ratoon crops) in subdivided plots with three replicates.

The data obtained were subjected to analysis of variance using the F-test. In case of a significant difference, the averages were compared by Tukey's test at a $5 \%$ probability using InfoStat ${ }^{\circledR}$ software (Infostat, 2004).

\section{Analyses}

To analyze the yield and nutritional value, three sugarcane samplings were performed, one at the end of each experimental year. An analysis of the stem yield was performed in a $3-\mathrm{m}^{2}$ area of each plot. After determining the fresh weight, three plants were randomly collected from each plot, each plant was separated into stem and tops + leaves, and the plants were identified and pre-dried in a forced air oven at $60^{\circ} \mathrm{C}$ for 72 hours or until they reached a constant weight. The plant material was then ground in a Willey mill to obtain $1.0-\mathrm{mm}$ particles to determine the contents of dry matter and crude protein on a DM basis according to the methodologies described by Silva and Queiroz (2002). The neutral detergent fiber and acid detergent fiber were analyzed by 
the Van Soest method described and simplified by Souza et al. (1999).

The in vitro digestibility was determined according to the methodology described by Tilley and Terry (1963). For this purpose, ruminal fluid was collected from three Holstein cows cannulated in the rumen with an average weight of $600 \mathrm{~kg}$. The animals were fed a diet composed of $80 \%$ of roughage (Cynodon grass hay) and $20 \%$ concentrate ( $20 \%$ crude protein - PB), water and mix mineral in abundance.

The ruminal inoculum was collected into thermal bottles that had been previously heated to $39^{\circ} \mathrm{C}$ and immediately taken to the laboratory, where it was homogenized and filtered through two layers of gauze. The filtrate was kept in a water bath at $39^{\circ} \mathrm{C}$ under $\mathrm{CO}_{2}$ saturation until the other solutions were added to reproduce the conditions in the ruminoreticular compartments. The formula (incubated DM/DM) x 100 was used to calculate the results. The Brix content (\%) of the sugarcane was measured using a field refractometer according to the methodology of Consecana (2006). For this purpose, three plants were randomly removed from each plot, and stem juice samples were collected. The stem juice drops were extracted from the $4^{\text {th }}$ internode beginning at the base of the plant and from the top of the last internode of the sheath.

\section{Results}

Yield and Nutritional Value of Plant Cane - Year I

For Year I, the yield of the RB 863129 variety was $23 \%$ higher $(\mathrm{P}<0.05)$ compared with those of the RB 867515 and RB 92579 varieties (Table 1). There was not a significant difference $(\mathrm{P}>0.05)$ for the neutral detergent fiber and acid detergent fiber contents between the studied varieties, with values similar to those observed by Oliveira et al. (2012), who obtained NDF values that varied from 35 to $63 \%$ and ADF values that varied from 21 to $36 \%$.

Table 1. Yield and nutritional value of sugarcane varieties.

\begin{tabular}{ccccccccc}
\hline \multirow{2}{*}{ Treatment } & $\begin{array}{c}\text { Yield } \\
\left(\mathrm{t} \mathrm{ha}^{-1}\right)\end{array}$ & $\begin{array}{c}\text { DM } \\
(\%)\end{array}$ & $\begin{array}{c}\text { NDF } \\
(\%)\end{array}$ & $\begin{array}{c}\text { ADF } \\
(\%)\end{array}$ & $\begin{array}{c}\text { CP } \\
(\%)\end{array}$ & IVDMD (\%) & $\begin{array}{c}\text { Brix } \\
(\%)\end{array}$ & NDF/Brix (\%) \\
\hline RB863129 & $144 \mathrm{a}$ & $19,2 \mathrm{a}$ & 54,8 & 36,0 & $3,38 \mathrm{a}$ & $64,7 \mathrm{a}$ & $18 \mathrm{a}$ & $3,04 \mathrm{a}$ \\
RB 867515 & $112 \mathrm{~b}$ & $19,4 \mathrm{a}$ & 61,8 & 37,5 & $1,70 \mathrm{~b}$ & $63,7 \mathrm{a}$ & $17 \mathrm{a}$ & $3,63 \mathrm{a}$ \\
RB 92579 & $111 \mathrm{~b}$ & $18,6 \mathrm{~b}$ & 55,1 & 32,5 & $1,89 \mathrm{~b}$ & $69,5 \mathrm{a}$ & $17 \mathrm{a}$ & $3,24 \mathrm{a}$ \\
CV (\%) & 18 & 8,3 & 7,6 & 3,5 & 4,8 & 8,0 & 2,1 & 12,3 \\
\hline
\end{tabular}

Averages followed by an lowercase letter in the columns do not differ by Tukey's test at a 5\% significance level.

The CP content was higher $(\mathrm{P}<0.05)$ for the $\mathrm{RB}$ 863129 variety, $53 \%$ higher on average than those of the other varieties. There was no difference between the varieties $(\mathrm{P}>0.05)$ in terms of the in vitro $\mathrm{DM}$ digestibility. The three evaluated varieties showed greater than $60 \%$ digestibility.

\section{Stem Yield - Year II and III}

There was an interaction $(\mathrm{P}<0.05)$ between varieties and doses of nitrogen fertilizer for the stem yield in the first and second ratoon crops (Table 2).
The highest yield values $(\mathrm{p}<0.05)$ were observed for the RB 92579 variety at doses of 80 and $140 \mathrm{~kg} \mathrm{~N}$ $\mathrm{ha}^{-1}$ for the first and second ratoon, respectively.

For all the varieties, a yield increase was observed with increased $\mathrm{N}$ dosage. However, for the $\mathrm{RB}$ 867515 and RB 92579 varieties in the first ratoon and for the RB 867515 and RB 863129 varieties in the second ratoon, this increase was only observed at a dose of $120 \mathrm{~kg} \mathrm{~N} \mathrm{ha}^{-1}$ followed by a decrease in yield at a dose of $140 \mathrm{~kg} \mathrm{~N} \mathrm{ha}^{-1}$. 
Table 2. Stem yield $\left(\mathrm{t} \mathrm{ha}^{-1}\right)$ from the first and second ratoon crops of sugarcane varieties in relation to nitrogen fertilizer doses.

\begin{tabular}{|c|c|c|c|c|c|}
\hline \multicolumn{6}{|c|}{ Stem $t$ ha $^{-1}$} \\
\hline $1^{\circ}$ Ratoon & \multicolumn{5}{|c|}{ Nitrogen rate $\left(\mathrm{kg} \mathrm{ha}^{-1}\right)$} \\
\hline Variety & 0 & 60 & 80 & 120 & 140 \\
\hline RB 867515 & $65,7 \mathrm{Bb} \alpha$ & $82,4 \mathrm{ABb} \alpha$ & $80,8 \mathrm{ABb} \alpha$ & $96,2 \mathrm{Ab} \alpha$ & $62,5 \mathrm{Bb} \alpha$ \\
\hline RB 863129 & $58,8 \mathrm{Cb} \alpha$ & $69,2 \mathrm{BCb} \alpha$ & $86,5 \mathrm{ABb} \alpha$ & $86,2 \mathrm{ABb} \alpha$ & $94,4 \mathrm{Aa} \alpha$ \\
\hline RB 92579 & $110,6 \mathrm{Ba} \alpha$ & $116,5 \mathrm{ABa} \alpha$ & $134,3 \mathrm{Aa} \alpha$ & $135,6 \mathrm{Aa} \alpha$ & $109,3 \mathrm{Ba} \alpha$ \\
\hline $2^{\circ}$ Ratoon & \multicolumn{5}{|c|}{ Nitrogen rate $\left(\mathrm{kg} \mathrm{ha}^{-1}\right)$} \\
\hline Variety & 0 & 60 & 80 & 120 & 140 \\
\hline RB 867515 & $65,7 \mathrm{Bab} \alpha$ & $82,4 \mathrm{ABa} \alpha$ & $80,7 \mathrm{ABb} \alpha$ & $96,1 \mathrm{Aa} \alpha$ & $68,1 \mathrm{Bb} \alpha$ \\
\hline RB 863129 & $40,8 \mathrm{Cb} \beta$ & $77,6 \mathrm{Ba} \alpha$ & $106,0 \mathrm{Aa} \alpha$ & $95,0 \mathrm{Ba} \alpha$ & 105,9 Aa $\alpha$ \\
\hline RB 92579 & $76,0 \mathrm{Ca} \beta$ & $75,4 \mathrm{Ca} \beta$ & $81,3 \mathrm{BCab} \beta$ & $102,5 \mathrm{Ba} \beta$ & $128,8 \mathrm{Aa} \beta$ \\
\hline
\end{tabular}

Averages followed by an uppercase letter in the rows, lowercase letters in the columns, and Greek letters in the tables do not differ by Tukey’s test at a 5\% significance level. CV $(\%)=16.65$.

For the second ratoon, a greater variation was observed in the yield (from 40.87 to 128.80 ), where the greatest yield was obtained for the RB 92579 variety at the dose of $140 \mathrm{~kg} \mathrm{~N} \mathrm{ha}^{-1}$. The lowest yield for the first ratoon was observed for the RB 863129 variety with the control treatment, which was $40 \%$ lower on average than those for the other treatments.

In addition to greater stem production, the RB 92579 variety also had the highest agronomic efficiency at the dose of $140 \mathrm{~kg} \mathrm{~N} \mathrm{ha}^{-1}$, which was $59 \%$ greater than that of the control (without the application of $\mathrm{N}$ ). The response of the ratoon was also positive for the other treatments with the application of 60,80 , and $120 \mathrm{~kg} \mathrm{~N} \mathrm{ha}^{-1}$.

Regarding the RB 863129 variety, which had the highest stem yield in the plant cane crop, its average yield in the second ratoon was lower than that observed for the RB 92579 variety. The treatments that obtained the highest yield values were for 80 and $140 \mathrm{~kg} \mathrm{~N} \mathrm{ha}^{-1}(\mathrm{P}<0.05)$, which both had an average of $106 \mathrm{t} \mathrm{ha}^{-1}$ of stems and a yield $38 \%$ higher on average than that obtained from the control treatment.

Overall, the lowest stem yields in the second ratoon were obtained from the RB 867515 variety without observing any interaction between the experimental years for any of the doses evaluated. For the variety RB 863129, a temporal effect on yield was only observed for the control treatment. In the first ratoon, the stem yield was $30 \%$ higher than in the second ratoon for the control treatment. For the RB 92579 variety, there was a temporal effect for all of the treatments, with higher yield values for the first ratoon compared with the second ratoon for the majority of treatments with the exception of the $140 \mathrm{~kg} \mathrm{~N} \mathrm{ha}^{-1}$ dose. The overall average stem yield of the first ratoon was greater than that for the second ratoon. This finding may be explained by the diameter of the stems, which gradually decreased over time; thus, with the decrease in the stem diameter due to successive cuts, the number of tillers of clumps also decreased over time, and consequently, the ratoon cane yield decreased.

\section{Dry Matter Content in the Stems $-1^{\text {st }}$ and $2^{\text {nd }}$ Ratoon crops}

The dry matter content for the first and second ratoon crops varied from 20.1 to $25.6 \%$, which are within the expected values for sugarcane with a resprout age of 10 months. There was no interaction between the different nitrogen doses, varieties, and experimental years (Table 3 ). 
Table 3. DM content of the stems from the first and second ratoon crops of the three sugarcane varieties in relation to increasing doses of nitrogen fertilizer.

\begin{tabular}{cccccc}
\hline \multicolumn{6}{c}{ Dry mater, \% } \\
\hline $1^{\circ}$ Ratoon & 0 & 60 & Nitrogen rate $\left(\mathrm{kg} \mathrm{ha}^{-1}\right)$ \\
\hline Variety & 0 & 80 & 120 & 140 \\
\hline RB 8675515 & $24,1 \mathrm{Aa} \alpha$ & $25,1 \mathrm{Aa} \alpha$ & $25,1 \mathrm{Aa} \alpha$ & $25,1 \mathrm{Aa} \alpha$ & $25,0 \mathrm{Aa} \alpha$ \\
RB 863129 & $25,0 \mathrm{Aa} \alpha$ & $25,6 \mathrm{Aa} \alpha$ & $25,6 \mathrm{Aa} \alpha$ & $25,3 \mathrm{Aa} \alpha$ & $25,6 \mathrm{Aa} \alpha$ \\
RB 92579 & $25,0 \mathrm{Aa} \alpha$ & $25,6 \mathrm{Aa} \alpha$ & $25,5 \mathrm{Aa} \alpha$ & $25,0 \mathrm{Aa} \alpha$ & $25,9 \mathrm{Aa} \alpha$ \\
\hline \multicolumn{5}{c}{ Nitrogen rate $\left(\mathrm{kg} \mathrm{ha}^{-1}\right)$} \\
\hline 20 & 60 & 80 & 120 & 140 \\
\hline Ratoon & 0 & $24,3 \mathrm{Aa} \alpha$ & $25,6 \mathrm{Aa} \alpha$ & $24,6 \mathrm{Aa} \alpha$ \\
RB 8675515 & $24,5 \mathrm{Aa} \alpha$ & $24,2 \mathrm{Aa} \alpha$ & $25,0 \mathrm{Aa} \alpha$ & $25,1 \mathrm{Aa} \alpha$ & $25,0 \mathrm{Aa} \alpha$ \\
RB 92579 963129 & $24,2 \mathrm{Aa} \alpha$ & $24,4 \mathrm{Aa} \alpha$ & $24,1 \mathrm{Aa} \alpha$ & $25,3 \mathrm{Aa} \alpha$ & $25,0 \mathrm{Aa} \alpha$ \\
\hline
\end{tabular}

Averages followed by an uppercase letter in the rows, lowercase letters in the columns, and Greek letters in the tables do not differ by Tukey's test at a 5\% significance level. CV $(\%)=6.18$.

Crude Protein $-1^{\text {st }}$ and $2^{\text {nd }}$ Ratoon crops

Regarding the stem CP contents in the $1^{\text {st }}$ sugarcane ratoon crop, there was a significant difference between doses for the RB 863129 and RB 92579 varieties, whereas no differences were observed between the varieties and nitrogen doses in the $2^{\text {nd }}$ ratoon. In the RB 863129 variety, the best $\mathrm{CP}$ contents were observed at doses of 120 and $140 \mathrm{~kg} \mathrm{~N} \mathrm{ha}{ }^{-1}$, with values of 2.49 and $2.19 \% \mathrm{CP}$, respectively. In the RB 92579 variety, the best $\mathrm{CP}$ value found was with the dose of $120 \mathrm{~kg} \mathrm{~N} \mathrm{ha}^{-1}$, which was significantly different from the control treatment (Table 4).

Table 4. CP contents in the stem from the first and second ratoon crops of the three varieties of sugarcane with five nitrogen fertilization treatments.

\begin{tabular}{cccccc}
\hline \multicolumn{5}{c}{ Crude protein, \% } \\
\hline $1^{\circ}$ Ratoon & \multicolumn{5}{c}{ Nitrogen rate $\left.\left(\mathrm{kg} \mathrm{ha}^{-1}\right)\right)$} \\
\hline Variety & 0 & 60 & 80 & 120 & 140 \\
\hline RB 8675515 & $1,14 \mathrm{Aa} \alpha$ & $1,51 \mathrm{Aa} \alpha$ & $1,20 \mathrm{Aa} \alpha$ & $2,20 \mathrm{Aa} \alpha$ & $1,38 \mathrm{Aa} \alpha$ \\
RB 863129 & $1,23 \mathrm{BCa} \alpha$ & $1,02 \mathrm{Ca} \alpha$ & $1,39 \mathrm{BCa} \alpha$ & $2,49 \mathrm{Aa} \alpha$ & $2,19 \mathrm{ABa} \alpha$ \\
RB 925795 & $1,37 \mathrm{Ba} \alpha$ & $1,81 \mathrm{ABa} \alpha$ & $1,75 \mathrm{ABa} \alpha$ & $2,52 \mathrm{Aa} \alpha$ & $1,64 \mathrm{ABa} \alpha$ \\
\hline $2^{\circ}$ Ratoon & 0 & 60 & Nitrogen rate $\left(\mathrm{kg} \mathrm{ha}^{-1}\right)$ \\
\hline Variety & $1,54 \mathrm{Aa} \alpha$ & $1,56 \mathrm{Aa} \alpha$ & $2,34 \mathrm{Aa} \alpha$ & $2,19 \mathrm{Aa} \alpha$ & $2,05 \mathrm{Aa} \alpha$ \\
\hline RB 8675515 & $1,94 \mathrm{Aa} \alpha$ & $1,83 \mathrm{Aa} \alpha$ & $1,70 \mathrm{Aa} \alpha$ & $1,95 \mathrm{Aa} \alpha$ & $2,04 \mathrm{Aa} \alpha$ \\
RB 863129 & $2,09 \mathrm{Aa} \alpha$ & $1,74 \mathrm{Aa} \alpha$ & $2,00 \mathrm{Aa} \alpha$ & $1,75 \mathrm{Aa} \alpha$ & $2,39 \mathrm{Aa} \alpha$ \\
RB 925795 &
\end{tabular}

Averages followed by an uppercase letter in the rows, lowercase letters in the columns, and Greek letters in the tables do not differ by Tukey's test at a 5\% significance level. CV $(\%)=10.19$.

\section{Neutral Detergent Fiber $-1^{\text {st }}$ and $2^{\text {nd }}$ Ratoon crops}

Table 5 shows the average values for the neutral detergent fiber of the stem fraction from the studied sugarcane varieties. Considering the responses to the treatments for each variety and the interaction between varieties and treatments, a significant difference was found in the NDF. 
Table 5. NDF contents in the stem from the first and second ratoon crops of the three sugarcane varieties with five nitrogen fertilization treatments.

\begin{tabular}{cccccc}
\hline \multicolumn{5}{c}{ Neutral detergent fiber, $\%$} \\
\hline $1^{\circ}$ ratoon & 0 & 60 & 80 & 120 & 140 \\
\hline Variety & $53,9 \mathrm{Aa} \beta$ & $50,4 \mathrm{Cb} \alpha$ & $53,2 \mathrm{Aa} \alpha$ & $47,6 \mathrm{Bb} \beta$ & $51,6 \mathrm{Aa} \alpha$ \\
RB 867515 & $56,5 \mathrm{Aa} \alpha$ & $42,0 \mathrm{Dc} \beta$ & $45,6 \mathrm{Cb} \alpha$ & $57,5 \mathrm{Aa} \alpha$ & $50,9 \mathrm{Ba} \beta$ \\
RB 863129 & $56,9 \mathrm{Aa} \alpha$ & $54,0 \mathrm{Aa} \alpha$ & $55,6 \mathrm{Aa} \alpha$ & $55,7 \mathrm{Aa} \alpha$ & $41,2 \mathrm{Bb} \beta$ \\
RB 92579 & 0 & 60 & Nitrogen rate $\left(\mathrm{kg} \mathrm{ha}^{-1}\right)$ \\
\hline $2^{\circ}$ ratoon & 50 & 120 & 140 \\
\hline Variety & $58,2 \mathrm{Aa} \alpha$ & $51,0 \mathrm{Aa} \alpha$ & $41,3 \mathrm{Bb} \beta$ & $55,2 \mathrm{Aa} \alpha$ & $55,1 \mathrm{Ab} \alpha$ \\
\hline RB 867515 & $56,6 \mathrm{Aa} \alpha$ & $45,8 \mathrm{Cb} \alpha$ & $42,3 \mathrm{Db} \alpha$ & $50,9 \mathrm{Bb} \beta$ & $55,0 \mathrm{Ab} \alpha$ \\
RB 863129 & $56,1 \mathrm{Ba} \alpha$ & $41,2 \mathrm{Dc} \beta$ & $46,1 \mathrm{Ca} \beta$ & $56,3 \mathrm{Ba} \alpha$ & $62,1 \mathrm{Aa} \alpha$ \\
\hline RB 92579 &
\end{tabular}

Averages followed by an uppercase letter in the rows, lowercase letters in the columns, and Greek letters in the tables do not differ by Tukey's test at a $5 \%$ significance level. CV $(\%)=2.08$.

The NDF values exhibited large variability with a difference of $20 \%$ between the highest value $(62.1 \%)$ and lowest value $(41.2 \%)$, both of which were observed in the RB 92579 variety in the $2^{\text {nd }}$ ratoon.

For all the varieties, regardless of the experimental year, the best NDF content differed from that of the control treatment $(\mathrm{p}<0.05)$, which demonstrates that nitrogen fertilization positively affects the reduction of the NDF fraction in sugarcane. Regarding the interaction between the different nitrogen doses and the studied varieties, there was a difference in the NDF contents at all $\mathrm{N}$ doses according to the variety used, and within each dose, the variation between varieties was $10.6 \%$ on average. For the dose of $60 \mathrm{~kg} \mathrm{~N} \mathrm{ha}{ }^{-1}$, there was a difference between the years for all the varieties, whereas for the control treatment, a difference was only observed between the $1^{\text {st }}$ and $2^{\text {nd }}$ ratoon for the RB 867515 variety, where the NDF content was $4.3 \%$ greater for the $2^{\text {nd }}$ ratoon relative to the $1^{\text {st }}$ ratoon. In this variety, differences were also observed in the NDF contents between the years at doses of 80 and $120 \mathrm{~kg} \mathrm{~N} \mathrm{ha}^{-1}$, with a variation of 11.8 and $7.6 \%$ from the first to the second ratoon, respectively. However, the trends were different because for the dose of $80 \mathrm{~kg} \mathrm{~N} \mathrm{ha}^{-1}$, there was a decrease in the NDF content from the $1^{\text {st }}$ ratoon to the $2^{\text {nd }}$ ratoon, whereas there was an increase from the $1^{\text {st }}$ ratoon to the $2^{\text {nd }}$ ratoon when a dose of $120 \mathrm{~kg} \mathrm{~N}^{-1}$ was used.

For the RB 863129 variety, differences were observed in the NDF contents between years at the doses of 120 and $140 \mathrm{~kg} \mathrm{~N}^{-1}$ in addition to the 60 $\mathrm{kg} \mathrm{N} \mathrm{ha}^{-1}$ already mentioned. The RB 92579 variety in turn exhibited differences between years at doses of 60,80 , and $140 \mathrm{~kg} \mathrm{~N} \mathrm{ha}^{-1}$, and the best NDF result in terms of nutritional quality was observed in the first ratoon with $140 \mathrm{~kg} \mathrm{~N} \mathrm{ha}{ }^{-1}$.

\section{Acid Detergent Fiber $-1^{\text {st }}$ and $2^{\text {nd }}$ Ratoon crops}

The acid detergent fiber values varied from $26.4 \%$ to $31.8 \%$ in the first ratoon and from $20.8 \%$ to $32.7 \%$ in the second ratoon (Table 6).

Regarding the stem ADF contents in the $1^{\text {st }}$ sugarcane ratoon, there was a significant difference between the nitrogen fertilizer doses for the RB 863129 and RB 92579 varieties, with distinct behaviors in the ADF contents of each studied treatment within these varieties. A difference was observed for all the varieties in the second ratoon. 
Table 6. ADF contents in the stem from the first and second ratoon crops of the three sugarcane varieties with five nitrogen fertilization treatments.

\begin{tabular}{cccccc}
\hline \multicolumn{5}{c}{ Acid detergent fiber, $\%$} \\
\hline $1^{\circ}$ Ratoon & 0 & 60 & Nitrogen rate $\left(\mathrm{kg} \mathrm{ha}^{-1}\right)$ \\
\hline Variety & $29,2 \mathrm{Aa} \alpha$ & $29,8 \mathrm{Aa} \alpha$ & $29,4 \mathrm{Aa} \alpha$ & $28,1 \mathrm{Aa} \alpha$ & $30,5 \mathrm{Aa} \alpha$ \\
RB 867515 & $29,3 \mathrm{ABa} \alpha$ & $28,1 \mathrm{Ba} \alpha$ & $31,7 \mathrm{ABa} \alpha$ & $31,4 \mathrm{ABa} \alpha$ & $31,8 \mathrm{Aa} \alpha$ \\
RB 863129 & $26,4 \mathrm{Ba} \alpha$ & $29,7 \mathrm{ABa} \alpha$ & $31,8 \mathrm{Aa} \alpha$ & $30,3 \mathrm{Aa} \alpha$ & $28,5 \mathrm{ABa} \alpha$ \\
RB 92579 & 0 & 60 & Nitrogen rate $\left(\mathrm{kg} \mathrm{ha}^{-1}\right)$ \\
\hline $2^{\circ}$ Ratoon & $31,9 \mathrm{Aa} \alpha$ & $31,8 \mathrm{Aa} \alpha$ & $25,5 \mathrm{Bb} \beta$ & $27,7 \mathrm{Ba} \alpha$ & $32,7 \mathrm{Aa} \alpha$ \\
\hline Variety & $26,2 \mathrm{Bb} \alpha$ & $29,7 \mathrm{Aab} \alpha$ & $20,8 \mathrm{Cc} \beta$ & $25,5 \mathrm{Ba} \beta$ & $25,7 \mathrm{Bb} \beta$ \\
\hline RB 867515 & $28,0 \mathrm{ABb} \alpha$ & $30,9 \mathrm{ABa} \alpha$ & $24,5 \mathrm{Ca} \beta$ & $31,2 \mathrm{Aa} \alpha$ \\
RB 863129 & $27,6 \mathrm{BCb} \alpha$ & 28,0
\end{tabular}

Averages followed by an uppercase letter in the rows, lowercase letters in the columns, and Greek letters in the tables do not differ by Tukey's test at a 5\% significance level. CV $(\%)=3.85$.

For the first ratoon, a difference of $3.6 \%$ between the lowest and highest ADF values was observed for the RB 863129 variety, whereas this difference was 5.3\% in the RB 92579 variety. In terms of nutritional quality, the RB 92579 variety in the control treatment showed the best result for $\operatorname{ADF}(26.4 \%)$, with the lowest value, which differed significantly from the doses of 80 and $120 \mathrm{~kg} \mathrm{~N} \mathrm{ha-}$ ${ }^{1}$. In the second ratoon, the best ADF value (20.8\%) was found in the RB 863129 variety, which differed significantly from all the doses.

\section{In Vitro Digestibility $-1^{\text {st }}$ and $2^{\text {nd }}$ Ratoon crops}

The IVDMD values for the first ratoon varied from 55 to $66 \%$, which are within the range expected for sugarcane with a resprout age between 10 and 12 months (OLIVEIRA et al., 2001). For the $2^{\text {nd }}$ ratoon, the values varied from 63 to $79 \%$, which is slightly higher than those reported in the literature for this period. There was no significant difference between the treatments and no interaction between the different nitrogen doses, varieties, and experimental years (Table 7).

Table 7. Digestibility content in the stem from the first and second ratoon crops of the three sugarcane varieties with five nitrogen fertilization treatments.

\begin{tabular}{|c|c|c|c|c|c|}
\hline \multicolumn{6}{|c|}{ In vitro Digestibility } \\
\hline $1^{\circ}$ Ratoon & \multicolumn{5}{|c|}{ Nitrogen rate $\left(\mathrm{kg} \mathrm{ha}^{-1}\right)$} \\
\hline Variedade & 0 & 60 & 80 & 120 & 140 \\
\hline RB 8675515 & $63,9 \mathrm{Aa} \alpha$ & $64,5 \mathrm{Aa} \alpha$ & $64,9 \mathrm{Aa} \alpha$ & $66,2 \mathrm{Aa} \alpha$ & $61,0 \mathrm{Aa} \alpha$ \\
\hline RB 863129 & $63,5 \mathrm{Aa} \alpha$ & $67,5 \mathrm{Aa} \alpha$ & $64,5 \mathrm{Aa} \alpha$ & $58,8 \mathrm{Aa} \alpha$ & $63,8 \mathrm{Aa} \alpha$ \\
\hline RB 92579 & $61,1 \mathrm{Aa} \alpha$ & $56,3 \mathrm{Aa} \alpha$ & $58,6 \mathrm{Aa} \alpha$ & $55,0 \mathrm{Aa} \alpha$ & $65,5 \mathrm{Aa} \alpha$ \\
\hline $2^{\circ}$ Ratoon & \multicolumn{5}{|c|}{ Nitrogen rate $\left(\mathrm{kg} \mathrm{ha}^{-1}\right)$} \\
\hline Variedade & 0 & 60 & 80 & 120 & 140 \\
\hline RB 8675515 & $68,4 \mathrm{Aa} \alpha$ & $79,8 \mathrm{Aa} \alpha$ & $71,8 \mathrm{Aa} \alpha$ & $63,2 \mathrm{Aa} \alpha$ & $64,6 \mathrm{Aa \alpha}$ \\
\hline RB 863129 & $68,4 \mathrm{Aa} \alpha$ & $67,9 \mathrm{Aa} \alpha$ & $75,5 \mathrm{Aa} \alpha$ & $68,9 \mathrm{Aa} \alpha$ & $69,2 \mathrm{Aa} \alpha$ \\
\hline RB 92579 & $69,5 \mathrm{Aa} \alpha$ & $71,3 \mathrm{Aa} \alpha$ & $68,7 \mathrm{Aa} \alpha$ & $69,7 \mathrm{Aa} \alpha$ & $68,0 \mathrm{Aa} \alpha$ \\
\hline
\end{tabular}

Averages followed by an uppercase letter in the rows, lowercase letters in the columns, and Greek letters in the tables do not differ by Tukey's test at a 5\% significance level, CV $(\%)=10.19$. 


\section{Discussion}

Yield and Nutritional Value of the Plant Cane-Year I

For the plant cane, the average yield of the three varieties was $122.33 \mathrm{t} \mathrm{ha}^{-1}$; this value is greater than the national average, which is currently 74.1 ton $\mathrm{ha}^{-1}$ (CONAB, 2014). The high yield can be justified by the environmental conditions during the experimental period, which influenced the tillering capacity of the varieties. An average temperature of $29^{\circ} \mathrm{C}$ was observed during the experimental period with an average precipitation of $153 \mathrm{~mm}$ in the first 180 days of the crop cycle (Figure 1), which is the period when the greatest tillering occurs, and consequently, there is a greater need for water availability and favorable temperatures. According to Inman-Bamber (2004), water deficit in the initial plant development phase limits sugarcane growth, development, and yield.

The RB 863129 variety showed a higher yield than the regional and national averages, which are 57 and $77 \mathrm{t} \mathrm{ha}^{-1}$, respectively (CONAB, 2011). This higher yield from RB 863129 is closely related to the growth data that were obtained for this variety in this experimental year, such as the number of plants (average of 14 plants per linear meter) and dry mass of the stems $\left(2,700 \mathrm{~g} \mathrm{plant}^{-1}\right)$; these parameters of this variety had the best results relative to the other varieties.

The average NDF of the three varieties in the plant cane crop was 57\%. In contrast to other tropical grasses, in sugarcane, the NDF contents are lower in the stems than in the leaves. This aspect is important because the NDF or cell wall represents the chemical fraction of the forage that has the closest correlation with animal intake and performance. The ADF is the less digestible fraction of the cell wall of forage plants, which consists almost entirely of lignin and cellulose (SILVA; QUEIROZ, 2002). According to Van Soest (1994), the greater the ADF content, the lower the digestibility will be, whereas the NDF has a negative correlation with forage intake with contents greater than $40 \% \mathrm{ADF}$ and $60 \% \mathrm{NDF}$, which are considered to be the limiting factors for digestibility and intake, respectively. Thus, these fractions were outside the limiting range for digestibility and intake in cattle.

Variations in the $\mathrm{CP}$ content between sugarcane varieties appear to be an intrinsic characteristic of each variety primarily due to different stem/leaf ratios between varieties. In addition, the $\mathrm{CP}$ content can vary according to the age of cutting because there are reports of a decreasing trend in the $\mathrm{CP}$ content throughout the crop cycle (MELLO et al., 2006).

The average in vitro digestibility of this study was similar to that obtained by Okano et al. (2006) and Carvalho et al. (2010). The NDF/Brix ratio had an average value of 3.3; this value can be accepted as adequate for this ratio between the analyzed varieties to avoid the higher NDF content of certain varieties limiting sugar intake by the animal, which is the component that provides the largest portion of digestible energy to the animal. A variety that contains a lower NDF content will allow the animal to consume more energy compared with another variety with a slightly lower sugar content and higher NDF content.

\section{Stem Yield - Year II and III}

The average stem yield for the RB 92579 variety was similar to the maximum yield per area according to data from the CONAB (2013), which refer to the 2011/2012 harvest. This is explained primarily by the maintenance of straw in the soil, by nutrient replenishment through fertilization, and by improved rainfall distribution during the vegetative cycle of the crop. The average temperature between the months of November 2010 and April 2011, which corresponds to the first 180 days of the crop cycle, varied between 23 and $26^{\circ} \mathrm{C}$; the water balance of the crop exhibited a short, reduced water deficit period (Figure 2). Thus, the environmental conditions that prevailed during this experimental 
year were determinant in the tillering capacity of the variety. As the air temperature increases to approximately $30^{\circ} \mathrm{C}$, there is a considerable increase in tillering and growth in terms of height, which favors a greater vegetative propagation of sugarcane (BONNETT et al., 2006).

The response of the ratoon cane to the application of nitrogen fertilizer can be explained by various factors. Anjos (1995) suggests that the response can be explained by differences in vigor for the root systems of the plant cane and ratoon crops, where the latter exhibits considerably less vigor, which makes them less able to absorb $\mathrm{N}$ at greater depths.

Nitrogen fertilization with increasing doses up to $180 \mathrm{~kg} \mathrm{~N}^{-1}$ resulted in a linear increase in stem yield of the second ratoon, where the effect is extended to the third ratoon (VITTI et al., 2007). In a study performed by Uribe (2010), the highest stem yield was found when $140 \mathrm{~kg} \mathrm{~N} \mathrm{ha-1}$ was applied, which confirms the results obtained in this study.

These results can be attributed to the effect of mineralization of $\mathrm{N}$ from the remaining straw, which accumulated from the previous years because, although the straw that remained on the soil surface had a low nitrogen content (compared with the soil reserve), the successive harvests without straw removal (via burning) must contribute to a higher accumulation of $\mathrm{N}$ in the soil over time. The positive effect of the presence of straw on sugarcane yield was also reported in other studies (SOUZA et al., 2005).

The majority of the literature available on nitrogen fertilization in plant cane or ratoon crops only evaluated one agricultural year and did not consider the response to the application of fertilizers in subsequent agricultural cycles due to the residual effect. This is important in sugarcane because this crop is a semi-perennial plant and uses reserves from the root system for resprouting (VITTI et al., 2007).

The sugarcane stem yield may be related to the genetic characteristics of the variety, namely, drought tolerance and rapid growth with high yield (SCHULTZ et al., 2010). In addition, sugarcane is an excellent soil nitrogen extractor due to the long cycle and abundant root system. Recent research data show that there is an enormous variation in the extraction of $\mathrm{N}$ by the various varieties of sugarcane in Brazil, which varies from 100 to $200 \mathrm{~kg} \mathrm{~N} \mathrm{ha}^{-1}$ for the production of $100 \mathrm{t} \mathrm{ha}^{-1}$ of stems. Of the extracted N, $18 \%$ to $64 \%$ is exported through the stems depending on the variety. In the study by Paes et al. (1997), who tested three sugarcane varieties in relation to three nitrogen fertilizer doses $(0,50$, and $\left.100 \mathrm{~kg} \mathrm{ha}^{-1} \mathrm{~N}\right)$, the authors obtained a positive response for the increase in stem yield per hectare in two of the three studied varieties and concluded that there is a difference in the efficiency of nitrogen use between sugarcane varieties.

\section{Dry Matter Content in the Stems $-1^{\text {st }}$ and $2^{\text {nd }}$ Ratoon crops}

The literature values are in the range of 20.4 to $33.9 \%$ DM. Sallas et al. (1992) evaluated the variation of the bromatological composition of 20 sugarcane varieties used as ruminant feed and observed variations in the DM content between 20.1 and $27.8 \%$. Orlando Filho et al. (1980) found that the dry matter accumulated in the leaf + green tops for the SP79-1011, RB72454, RB855113, RB867515, RB92579, RB93509, Co997, and CB 4176r varieties was higher than the amount accumulated in the stem up to 180 and 300 days after planting (DAP). These periods were similar to those observed in this study.

\section{Crude Protein $-1^{\text {st }}$ and $2^{\text {nd }}$ Ratoon crops}

Oliveira etal.(2012) evaluated the bromatological composition and in vitro digestibility of four sugarcane varieties, including RB 867515, and found a CP content that varied from 2.39 to $2.52 \%$. No effect of the cutting year was observed on the $\mathrm{CP}$ contents for the varieties and nitrogen doses. In the study by Viana et al. (2011), a linear effect was 
observed for the crude protein content in response to the applied nitrogen. This increase in protein content as a response to nitrogen fertilization is observed in various studies with other forage grasses (PUOLI et al., 1991; KERING et al., 2011).

Generally, sugarcane leaves have a nitrogen content five to six times higher than the stems, which is most likely due to the higher enzymatic activity in the leaves. However, because the stems represent $80 \%$ of the plant, the crude protein content in the entire plant rarely exceeds $2 \%$ of the DM.

\section{Neutral Detergent Fiber $-1^{\text {st }}$ and $2^{\text {nd }}$ Ratoon crops}

The variations in the NDF contents of this study are in accordance with those found by Nussio et al. (2006), who observed a large NDF variation ranging from 37.9 to $63.9 \%$ in sugarcane samples. This difference in percentage units is of great importance considering the limited capacity for NDF intake by animals.

In general, the NDF content of sugarcane is low compared with other tropical forages with high dry matter production potential per hectare. This fact is explained primarily by the cutting age of the plant, which occurred at 10 months; the cane had already reached maturity and contained a high sucrose content.

Korndorfer et al. (2002) compared the effect of nitrogen fertilization in seven sugarcane varieties and observed that the fiber content in the canes decreased as the nitrogen increased. According to Toppa et al. (2010) $\mathrm{N}$ increases the length of the sugarcane stems, which reduces the cell wall thickness, potentially reducing the percentage of fibers in the plant. In studies with other forage plants, a reduction in the NDF content has been attributed to nitrogen fertilization (DUPAS et al., 2010, FREITAS et al., 2012). The NDF from sugarcane exhibits low digestibility, $40 \%$ on average, and thus, the reduction in its levels leads to better quality roughage (MAEDA et al., 2011)
Acid Detergent Fiber $-1^{\text {st }}$ and $2^{\text {nd }}$ Ratoon crops

PATE et al. (2001) studied the nutritional value of commercial sugarcane varieties and observed a wide variation in the percentage of $\operatorname{ADF}(28.3 \%$ to $41.5 \%$ ), where 66 varieties were evaluated.

In general, a clear trend in the improvement of the ADF content with an increase in the nitrogen fertilizer dose was not observed in this study. The differences between the treatments with regard to the ADF content can be explained by the intrinsic characteristic of etiolation and internodal distance of each variety.

Other tropical forages have shown contradicting results regarding the response of the ADF content to increased nitrogen doses. Kering et al. (2011) analyzed the nutritional quality of Cynodon dactylon fertilized with four doses of nitrogen fertilizer, with the results showing a decrease of $25 \%$ in the ADF content at the highest $\mathrm{N}$ dose. In turn, Dupas et al. (2010) evaluated the effect of five $\mathrm{N}$ doses on the nutritional quality of marandu grass (Brachiaria brizantha, $c v$. Marandu) and observed that the NDF content decreased with increased nitrogen doses, whereas the ADF content was unaffected by fertilization.

\section{In Vitro Digestibility $-1^{\text {st }}$ and $2^{\text {nd }}$ Ratoon crops}

Despite the statistical similarity of the averages, the numerical differences between the varieties occurred due to factors such as the accumulation of sugars in the cane plant and the stage of plant maturity at the time of harvest (SUZUKI et al., 2010). The high IVDMD value is characteristic of sugarcane because this forage maintains high digestibility, including a slight increase at the end of the vegetative cycle that coincides with maturation. As in the work by Waramit et al. (2012), this study also did not find a consistent pattern in the response of the IVDMD to nitrogen fertilization. Thus, it was difficult to draw conclusions regarding the beneficial effect of nitrogen fertilization on the IVDMD. 
Rodrigues et al. (1997) studied 11 sugarcane varieties and observed high digestibility coefficients; the authors found variations between 67.57 and $77.23 \%$ in the IVDMD, though for the entire plant.

\section{Conclusions}

The RB 863129 sugarcane variety showed the best yield and nutritional quality as plant cane with a yield of $144 \mathrm{t} \mathrm{ha}^{-1}$ of stems, 54.80\% NDF, 36.0\% $\mathrm{ADF}, 3.38 \% \mathrm{CP}$, and a NDF/BRIX ratio of 3.04 . The RB 92579 variety exhibited a better yield together with the best nutritional parameters, with averages of $131 \mathrm{t} \mathrm{ha}^{-1}$ of stems, 26\% ADF, 41\% NDF, and $2.44 \% \mathrm{CP}$ in the $2^{\text {nd }}$ and $3^{\text {rd }}$ year after planting for nitrogen fertilizer doses of 120 and $140 \mathrm{~kg} \mathrm{~N} \mathrm{ha}^{-1}$. Thus, this variety is recommended for the soil and climatic conditions of the region.

Sugarcane yield and its nutritional quality can increase considerably with the appropriate management of nitrogen fertilization in ratoon crops. Additionally, the observed responses of the majority of the evaluated parameters were influenced by the variety type.

\section{References}

ABRANCHES, J. L.; BOLONHEZI, A. C. Desenvolvimento inicial de variedades e clones de canade-açúcar em Latossolo Vermelho Distrófico, Aparecida do Taboado - MS. Revista Brasileira de Ciências Agrárias, Recife, v. 6, n. 3, p. 369-375, 2011.

ANJOS, I. A. Avaliação do potencial forrageiro e industrial de variedades de cana-de-açúcar (canasoca), sob diferentes doses de nitrogênio. 1995. Dissertação (Mestrado em Fitotecnia) - Universidade Federal de Lavras. Lavras.

BERCHIELLI, T. T.; PIRESS, A. V.; OLIVEIRA, G. Nutrição de ruminantes. 2. ed. Jaboticabal: Funep, 2011. $616 \mathrm{p}$.

BOIN, C.; MATTOS, W. R. S.; D’ARCE, R. D. Cana de açúcar e seus subprodutos na alimentação de ruminantes. In: PARANHOS, S. B. Cana de açúcar, cultivo e utilização. Campinas: Fundação Cargil, 1987. v. 2, p. 805-856.
BONNETT, G. D.; HEWITT, M. L.; GLASSOP, D. Effects of high temperature on the growth and composition of sugarcane internodes. Australian Journal of Agricultural Research, Deakin, v. 57, n. 10, p. 10871095, 2006.

BONOMO, P.; CARDOSO, C. M. M.; PEDREIRA, M. S.; SANTOS, C. C.; PIRES, A. J. V.; SILVA, F. F. Potencial forrageiro de variedades de cana-de-açúcar para alimentação de ruminantes. Acta Scientiarum. Animal Sciences, Maringá, v. 31, n. 1, p. 53-59, 2009.

CARVALHO, M. V.; RODRIGUES, P. H. M.; LIMA, M. L. P.; ANJOS, I. A.; LANDELL, M. G. A.; SANTOS, M. V.; SILVA, L. F. P. Composição bromatológica e digestibilidade de cana-de-açúcar colhida em duas épocas do ano. Brazilian Journal of Veterinary Research and Animal Science, São Paulo, v. 47, n. 4, p. 298-306, 2010.

COMPANHIA NACIONAL DE ABASTECIMENTO - CONAB. Acompanhamento da safra brasileira: canade-açúcar, safra 2010/2011, terceiro levantamento, janeiro/2011. Brasília: Companhia Nacional de Abastecimento, 2011.19 p.

Acompanhamento da safra brasileira: cana-deaçúcar, safra 2012/2013, quarto levantamento, abril/2013. Brasília: Companhia Nacional de Abastecimento, 2013. $17 \mathrm{p}$.

- Acompanhamento da safra brasileira: canade-açúcar, safra 2013/2014, segundo levantamento, agosto/2014. Brasília: Companhia Nacional de Abastecimento, 2014. 17 p.

DUPAS, E.; BUZETTI, S.; SARTO, A. L. Dry matter yield and nutritional value of Marandu grass under nitrogen fertilization and irrigation in cerrado in São Paulo. Revista Brasileira de Zootecnia, Viçosa, MG, v. 39, n. 12, p. 2598-2603, 2010.

FREITAS, F. P.; FONSECA, D. M.; BRAZ, T. G. S.; MARTUSCELLO, J. A.; SANTOS, M. E. R. Forage yield and nutritive value of Tanzania grass under nitrogen supplies and plant densities. Revista Brasileira de Zootecnia, Viçosa, v. 41, n. 4, p. 864-872, 2012.

INMAN-BAMBER, N. G. Sugarcane water stress criteria for irrigation and drying off. Field Crops Research, Amsterdam, v. 89, n. 1, p. 107-122, 2004.

KERING, M. K.; GURETZKY, J.; FUNDERBURG, E.; MOSALI, J. Effect of nitrogen fertilizer rate and harvest season on forage yield, quality and macronutrient concentrations in Midland bermuda grass. Communications in Soil Science and Plant Analysis, New York, v. 42, n. 2011, p. 1958-1971, 2011. 
KORNDÖRFER, G.H.; COLOMBO, C.A.; CHIMELLO, M. A.; LEONI, P. L. C. Desempenho de variedades de cana-de-açúcar cultivadas com e sem nitrogênio. In: CONGRESSO NACIONAL DA SOCIEDADE DOS TÉCNICOS AÇUCAREIROS E ALCOOLEIROS DO BRASIL - STAB, 8., 2002, Recife. Anais... Recife: [s.n.], 2002. p. 234-238.

MAEDA, E. M.; ZEOULA, L. M.; JOBIM, C. C.; BERTAGLIA, F.; JONKER, R. C.; GERON, L. J. V.; HENRIQUE, D. S. Chemical composition, fermentation, in vitro digestibility and in situ degradability of sugar cane silages with Lactobacillus, urea and agricultural by product. Revista Brasileira de Zootecnia, Viçosa, v. 40, n. 12, p. 2866-2977, 2011.

MELLO, S. Q. S.; FRANÇA, A. F. S.; LIMA, M. L. M.; RIBEIRO, D. S.; MIYAGI, E. S.; REIS, J. G. Parâmetros do valor nutritivo de nove variedades de cana-de-açúcar cultivadas sob irrigação. Ciência Animal Brasileira, Goiânia, v. 7, n. 4, p. 373-380, 2006.

MUCHOVEJ, R. M.; NEWMAN, P. R. Nitrogen fertilization of sugarcane on a sandy soil: ii. soil and groundwater analyses. Journal of the American Society of Sugar Cane Technologists, Los Angeles, v. 24, n. 1, p. 210- 224, 2004.

NUSSIO, L. G.; SCHMIDT, P.; SCHOGOR, A. L. B.; MARI, L. J. Cana-de-açúcar como alimento para bovinos. In: SIMPÓSIO SOBRE MANEJO ESTRATÉGICO DA PASTAGEM, 3., 2006, Viçosa, MG. Anais... Viçosa, UFV, DZO, 2006. p. 277-328.

OKANO, K.; IIDA, Y.; SAMSURI, M.; PRASETYA, B.; USAGAWA, T.; WATANABE, T. Comparison of in vitro digestibility and chemical composition among sugarcane bagasses treated by four white-rot fungi. Animal Science Journal, Champaign, v. 77, n. 3, p. 308-313, 2006.

OLIVEIRA, M. D. S.; CASAGRANDE, A. A.; OLIVEIRA, E. F. S. Efeito da digestibilidade in vitro de variedades de cana-de-açúcar sobre seu valor como alimento para bovinos. Ars Veterinaria, Jaboticabal, v. 17, n. 3, p. 238-243, 2001.

OLIVEIRA, M. D. S.; REGO, A. C.; SFORCINI, M. P. R.; FREITAS JUNIOR, J. E.; SANTOS, J.; CARVALHO, M. V. Bromatological characteristics and in vitro digestibility of four sugarcane varieties subjected or not to the application of quicklime. Acta Scientiarum Animal Sciences, Maringá, v. 34, n. 4, p. 355-361, 2012.

PAES, J. M. V.; MARCIANO, N.; BRITO, C. H.; CARDOSO, A. A.; MARTINEZ, H. H. P.; MENDES, A. Estudo de espaçamentos e doses de nitrogênio na produção e em algumas características biométricas de três variedades de cana-de-açúcar. STAB, Viçosa, v. 15, n. 6, p. 18-20, 1997.
PATE, F. M.; ALVAREZ, J.; PHILLIPS, J. D.; EILAND, B. R. Sugarcane as a cattle feed: production and utilization. Florida: University of Florida, Cooperative Extension Service, 2001. 25 p.

PUOLI, J. R.; JUNG, G. A.; REID, R. L. Effects of nitrogen and sulfur on digestion and nutritive quality of warm-season grass hays for cattle and sheep. Journal of Animal Science, Champaign, v. 69, n. 2, p. 843-852, 1991.

RODRIGUES, A. A.; PRIMAVESI, O.; ESTEVES, S. N. Efeito da qualidade de variedades de cana-de-açúcar sobre seu valor como alimento para bovinos. Pesquisa Agropecuária Brasileira, Brasília, v. 32, n. 12, p. 1333 1338, 1997.

RAKKIYAPPAN, P.; THANGAVELU, S.; BHAGYALAKSHMI, K. V.; RADHAMANI, R. Uptake of nitrogen, phosphorus and potassium by some promising mid late maturing sugarcane clones. Sugar Tech, New Delhi, v. 9, n. 1, p. 23-27, 2007.

SALLAS, M.; AUMONT, G.; BIESSY, G.; MAGNIE, E. Effect of variety, stage of maturity and nitrate fertilization on nutritive values of sugar canes. Animal Feed Science and Technology, Amsterdam, v. 39, n. 3, p. 265-277, 1992.

SCHULTZ, N.; EDUARDO, L.; PEREIRA, M. G.; ZONTA, E. Efeito residual da adubação na canaplanta e da adubação nitrogenada e potássica na canasoca colhidas com e sem a queima da palhada. Revista Brasileira de Ciência do Solo, Viçosa, MG, v. 34, n. 3, p. 811-820, 2010.

SILVA, D. J.; QUEIROZ, A. C. Análise de alimentos: métodos químicos e biológicos. 3. ed. Viçosa, MG: Universidade Federal de Viçosa, 2002. 235 p.

SIQUEIRA, G. R.; ROTH, M. T. P.; MORETTI, M. H.; BENATTI, J. M. B.; RESENDE. F. D. Uso da cana-deaçúcar na alimentação de ruminantes. Revista Brasileira de Saúde e Produção Animal, Salvador, v. 13, n. 4, p. 991-1008, 2012.

SCARPARI, M. S.; BEAUCLAIR, E. G. F. Physiological model to estimate the maturity of sugarcane. Scientia Agricola, Piracicaba, v. 66, n. 5, p. 622-628, 2009.

SOUZA, G. B.; NOGUEIRA, A. R. A.; SUMI, L. N.; BATISTA, L. A. R. Método alternativo para a determinação de fibra em detergente neutro e detergente ácido. São Carlos: Embrapa Pecuária Sudoeste, 1999. 21 p.

SOUZA, Z. M.; PRADO, R. M.; PAIXÃO, A. C. S.; CESARIN, L. G. Sistemas de colheita e manejo da palhada de cana-de-açúcar. Pesquisa Agropecuária Brasileira, Brasília, v. 40, n. 3, p. 271-278, 2005. 
SUZUKI, T.; SAKAIGAICHI, T.; TERAJIMA, Y.; MATSUOKA, M.; KAMIYA, Y; HATTORI, I.; TANAKA, M. Chemical composition and in situ degradability of two varieties of sugarcane at different growth stages in subtropical Japan. Grassland Science in Europe, Tochigi, v. 56, n. 3, p. 134-140, 2010.

TILLEY, J. M. A.; TERRY, R. A. A two stage technique for the in vitro digestion of forage crops. Journal of the British Grassland Society, Oxford, v. 18, n. 2, p. 104-111, 1963.

TOPPA, E. V. B.; JADOSKI, C. J.; JULIANETTI, A.; HULSHOF, T.; ONO, E. O.; RODRIGUES, J. D. Aspectos da fisiologia de produção da cana-de-açúcar (Saccharum Officinarum L.). Applied Research \& Agrotechnology, Nata-PR, v. 3, n. 3, p. 215-221, 2010.

URIBE, R. A. M. Produtividade e estimativa de acúmulo da biomassa em soqueira de cana-de-açúcar irrigada por gotejamento subsuperficial com diferentes doses de $N$-fertilizante. 2010. Tese (Doutorado em Agronomia/ Irrigação e Drenagem) - Faculdade de Ciências Agronômicas, Universidade Estadual Paulista, Botucatu.
VAN SOEST, P. J. Nutritional ecology of the ruminant. Ithaca, New York: Cornel University Press, 1994. 476 p.

VITTI, A. C.; TRIVELIN, P. C. O.; GAVA, G. J. C.; PENATTI, C. P.; BOLOGNA, I. R.; FARONI, C. E.; FRANCO, H. C. J. F. Produtividade da cana-de-açúcar relacionada ao nitrogênio residual da adubação e do sistema radicular. Pesquisa Agropecuária Brasileira, Brasília, v. 42, n. 2, p. 249-256, 2007.

VIANA, M. C. M.; FREIRE, F. M.; FERREIRA, J. J.; MACÊDO, G. A. R.; CANTARUTTI, R. B.; MASCARENHAS, M. H. T. Adubação nitrogenada na produção e composição química do capim braquiária sob pastejo rotacionado. Revista Brasileira de Zootecnia, Viçosa, v. 40, n. 7, p. 1497-1503, 2011.

WARAMIT, N.; MOORE, K. J.; FALE, S. L. Forage quality of native warm-season grasses in response to nitrogen fertilization and harvest date. Animal Feed Science and Technology, Amsterdam, v. 174, p. 46-59, 2012. 
